\title{
Decadal variation in the trans-Pacific migration of northern bluefin tuna (Thunnus thynnus) coherent with climate-induced change in prey abundance
}

\section{JEFFREY J. POLOVINA}

Honolulu Laboratory, Southwest Fisheries Science Center, NMFS, NOAA, 2570 Dole Street, Honolulu, Hawaii 96822-2396, USA

\begin{abstract}
Northern bluefin tuna, Thunnus thynnus, apparently spawn only in the western Pacific and a portion of the juveniles migrate to the eastern Pacific. During the past decade, catches of northern bluefin in the eastern Pacific have declined. One possible cause for this decline, proposed by bluefin stock assessment studies, is a decline in the proportion of bluefin that migrate out of the western Pacific. This hypothesis is examined with several indices of the relative abundance of bluefin tuna in the western and eastern Pacific. These indices suggest a decline in the proportion of bluefin migrating to the eastern Pacific since 1977. This period of reduced bluefin migration coincides with a period when a prey of bluefin, Japanese sardine, Sardinops melanosticta, were abundant off Japan. It is hypothesized that in years when sardines are abundant off Japan, a higher proportion of bluefin stay in the western Pacific compared with years when sardines are scarce. Currently, the adundance of sardines off Japan is declining. If this decline continues, this hypothesis predicts an increase in bluefin migrating north of Hawaii and into the eastern Pacific.
\end{abstract}

Key words: bluefin tuna, migration, climate change, prey abundance, North Pacific, Japanese sardine

\section{INTRODUCTION}

Bluefin tuna, Thunnus thynnus, are among the largest bony fishes, exceeding $3 \mathrm{~m}$ and $500 \mathrm{~kg}$, and have a 30 year life span (Foreman and Ishizuka, 1990). They are highly valued in the fresh fish market and, in some instances, command ex-vessel prices of $\$ 15-26 \mathrm{~kg}^{-1} \mathrm{ex}$ vessel and $\$ 35-77 \mathrm{~kg}^{-1}$ at the Tokyo fish auction (Foreman and Ishizuka, 1990). The Pacific northern

Received for publication 2 November 1995

Accepted for publication 20 January 1996 bluefin is thought to be a single population which spawns only in the western Pacific, south of Japan and in the Sea of Japan (Sund et al., 1981). Some bluefin remain in the western Pacific while others migrate to the eastern Pacific, either during the latter half of their first year or during their second year, where they remain for several years before returning to the western Pacific to spawn (Bayliff, 1994). Tagging data indicate that the migration from the western Pacific to the eastern Pacific can take as little as 6 months whereas the return migration may take 2 years or more (Bayliff, 1994).

In the western Pacific, bluefin are fished largely off the coast of Japan with a range of gears including trolling, traps, purse seines, baitboats, gill nets, longlines and handlines, while in the eastern Pacific they are caught off the coasts of Mexico and the US, with commercial harvests taken primarily with purse seines (Bayliff, 1994). During the past decade, declines in catch and catch rates for bluefin in the eastern Pacific have been observed and it has been suggested that this decline is due to fewer bluefin migrating to the eastern Pacific (IATTC, 1994). This paper will examine this hypothesis with the most recent catch data from both the eastern and western Pacific. I suggest a link between the transPacific migration dynamics and the population dynamics of an important prey item of bluefin in the western Pacific, Japanese sardine, Sardinops melanosticta.

\section{DATA AND METHODS}

Bluefin are caught in the western Pacific in all age groups ranging from less than 1-year-olds (age class 0 ) to over 6-year-olds. Catch-at-age data for the western Pacific, from Japanese fisheries, are available from 1965 to 1986 (Bayliff, 1994) and 1987 to 1992 (pers. comm., Y. Ishizuka, NRIFS, Japan). In the eastern Pacific, bluefin are caught as 1- to 4-year-olds and catch-at-age data are available from 1951 to 1991 (Bayliff, 1994). Population estimates by age of bluefin in the eastern and western Pacific by year class (1966-1982) have been computed from cohort analysis (Bayliff, 1993). An index of fishing effort for bluefin is available for the period 1960-1991, computed as the number of days fishing for each vessel targeting tuna within an area with suitable sea surface 
temperature for bluefin (Bayliff, 1996). Lastly, as an index of sardine biomass available to bluefin off Japan, catches of Japanese sardines from the north-eastern side of Japan, in the region that coincides with the main fishing grounds for the bluefin, are available from 1951 to 1990 (Kawai, 1993).

\section{RESULTS}

Total bluefin tuna catches since 1951 show a substantial decline in eastern Pacific catches beginning in the late 1970s, with low catches persisting through 1992 (Fig. 1). No comparable decline is seen in western Pacific catches (Fig. 1). Age-specific estimates of population size are available from cohort analysis (Bayliff, 1993) and show a similar decline in abundance in the eastern Pacific. Specifically, the estimated population size from VPA of age-2 bluefin, a dominant age class in eastern Pacific catches, shows a decline in the eastern Pacific population size and an increase in the western Pacific population size in the late 1970s (Fig. 2). When eastern Pacific catches are adjusted for fishing effort, the catch per unit of effort (CPUE) shows substantially lower levels during the 1980s, except for the years 1985 and 1986, relative to the two previous decades (Fig. 3).

The catch-at-age distribution for the eastern Pacific shows that mean annual catches for all age classes were lower during 1980-1990 compared with 1965-1975 (Fig. 4). However, in the western Pacific, mean annual catches of age- 0 and age- 1 bluefin did not change, while catches of age- 2 to age- 5 fish increased in 19801990 (Fig. 5).
The proportion of age classes 1 to 4 caught in the western Pacific represented about $40 \%$ of combined eastern and western Pacific catches during 1965-1975 and about $80 \%$ after 1980 (Fig. 6). The increase in this proportion is consistent with the increase in catches of Japanese sardine off the north-east of Japan (Fig. 6). An overlay of the eastern Pacific CPUE (Fig. 3) with the Japanese sardine catch off the north-east of Japan shows, with the exception of 1985 and 1986, an inverse relationship (Fig. 7).

\section{DISCUSSION}

The decline in relative abundance of age 1-4 bluefin in the eastern Pacific indicated by the CPUE trend, as well as estimated absolute abundance from cohort analysis, could result from a variety of hypotheses which include: (1) a change in the local distribution of bluefin in the eastern Pacific, (2) a decline in recruitment of age- 0 bluefin in the western Pacific, (3) an increase in the harvest of bluefin in the western Pacific before they migrate to the eastern Pacific, and (4) a reduction in the proportion of bluefin that migrate from the western Pacific to the eastern Pacific.

The first hypothesis, that a change in the distribution of bluefin in the eastern Pacific reduced the availability of the population to the fishery, has been examined with catch rate maps and there is no indication that this accounts for the decline in the 1980s (IATTC, 1994). The second hypothesis, that there has been a decline in recruitment of age- 0 bluefin, is difficult to assess without fishing effort from the western Pacific. However, the

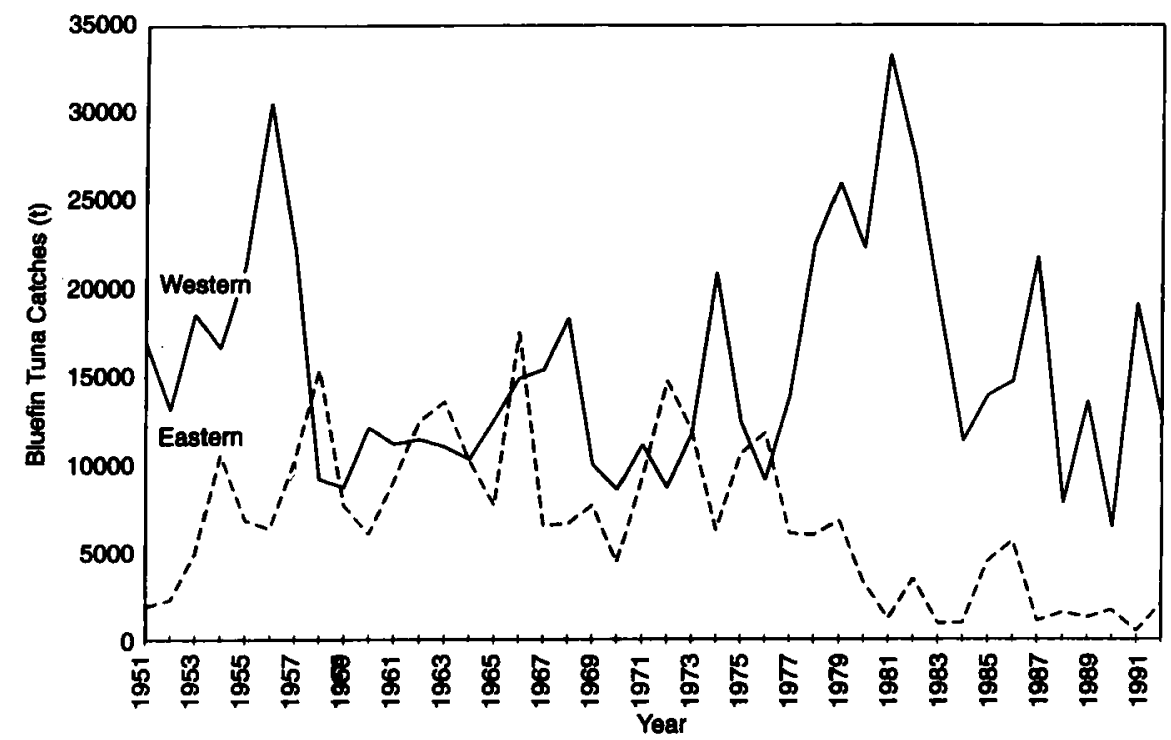

(C) 1996 Blackwell Science Ltd., Fish. Oceanogr., 5, 114-119.
Figure 1. Landings of northern Pacific bluefin tuna (short tons; 1 short ton $=907.19 \mathrm{~kg}$ ) from the western and eastern Pacific Ocean, 1951-1992. 
Figure 2. Estimates of number of age-2 bluefin in western and eastern Pacific, 1968-1984.

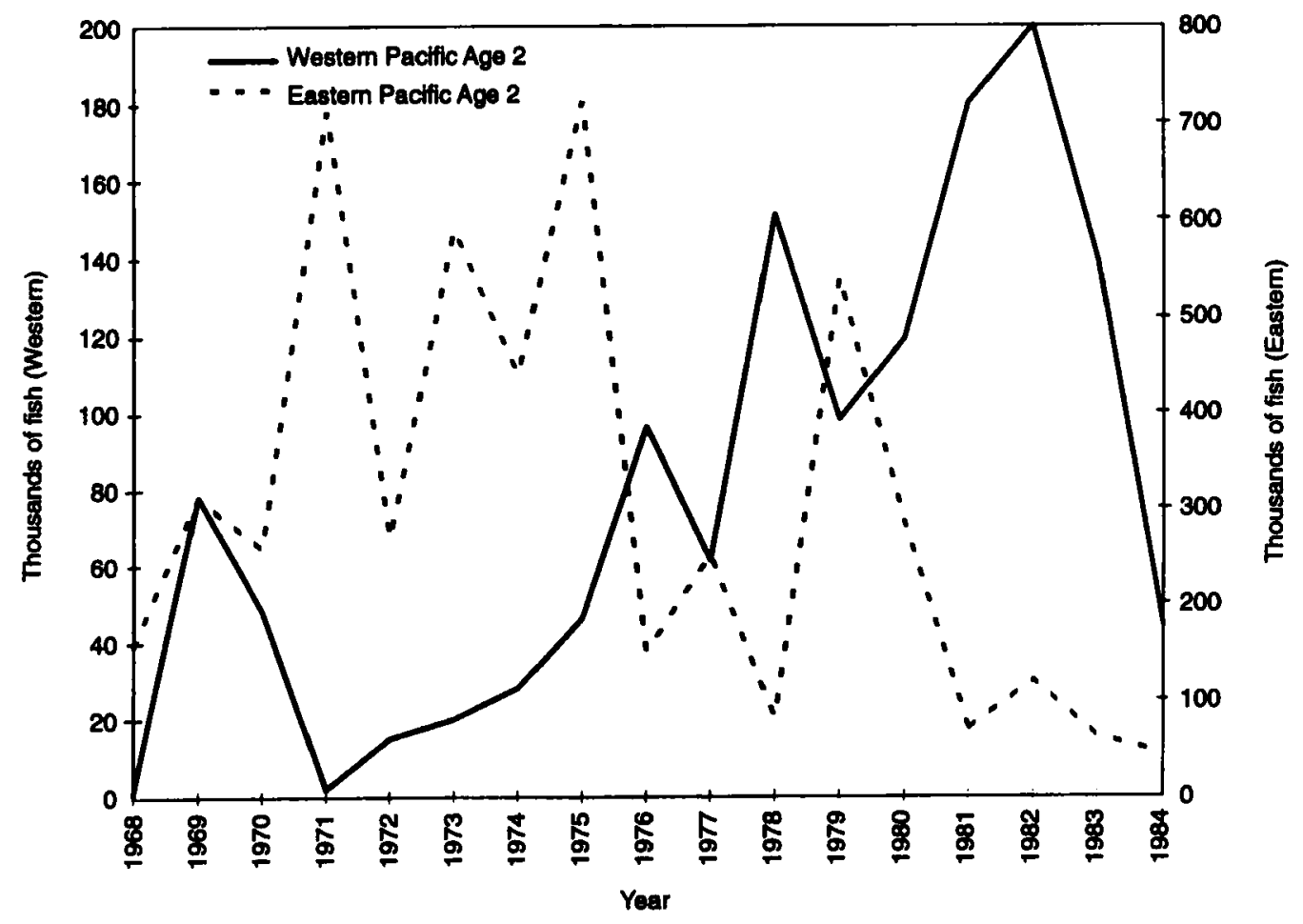

lack of a decline in the catch of age- 0 fish in the western Pacific in the 1980s (Fig. 5) argues against this hypothesis (IATTC, 1994). The third hypothesis, that the decline in the eastern Pacific is due to an increase in harvest of juvenile bluefin in the western Pacific before they migrate, is also not supported by catch data because the mean catch of age- 0 and age- 1 fish in the
1980 s is virtually identical to that in 1965-1975 in the western Pacific (Fig. 5). Finally, the fourth hypothesis, that the decline is due to a decline in the proportion of bluefin that migrate from the western Pacific to the eastern Pacific, is supported by two pieces of evidence. Firstly, there is an increase in the mean catch of age- 2 to age- 5 bluefin in the western Pacific during 1980-1990

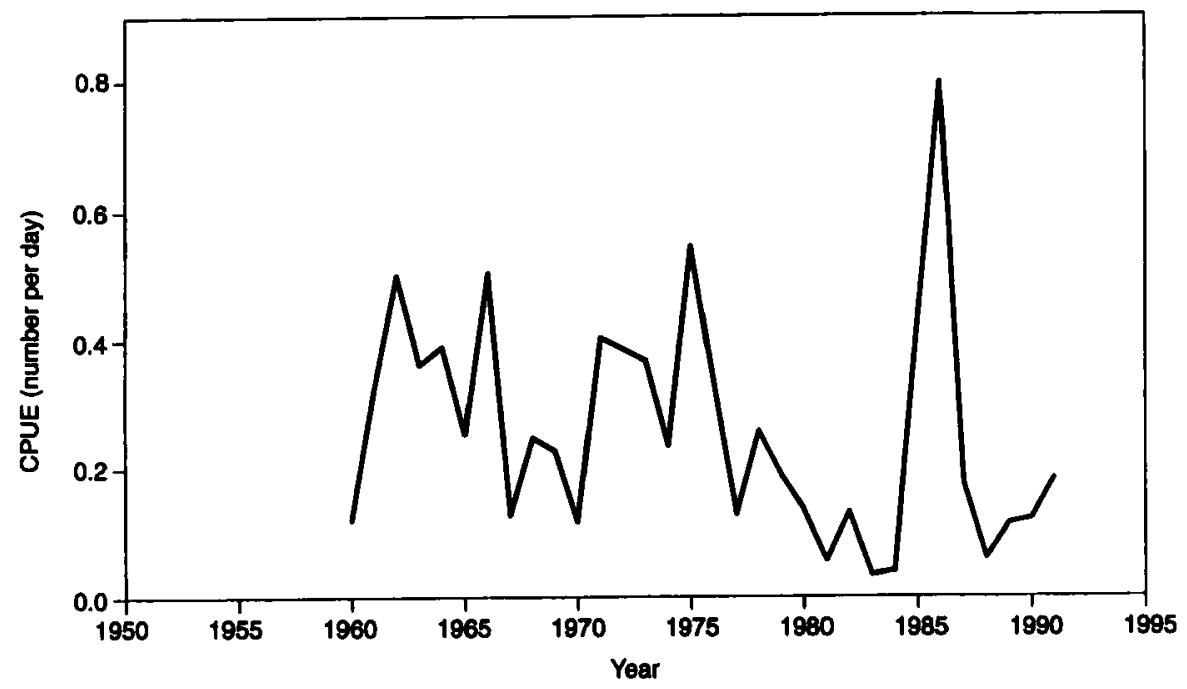

Figure 3. Bluefin CPUE (number of age 1-4 bluefin day ${ }^{-1}$ of fishing) in the eastern Pacific Ocean, 19601991. 
Figure 4. Catch-at-age of northern bluefin (thousand fish) in the eastern Pacific Ocean during 1965-1975 and 1980-1990.

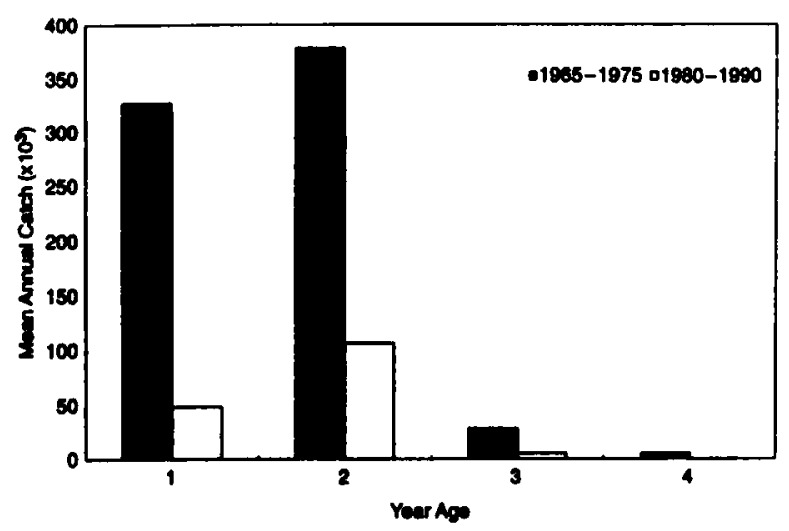

(Figs 2,5). This would be expected if fewer bluefin migrated to the eastern Pacific, because more age- 2 to age-5 fish would be available to the fishery in the western Pacific. Secondly, there is the increase in the proportion of North Pacific age-1 to age-4 fish caught in the western Pacific (Fig. 6). The age-1 to age-4 fish are caught in both the western and eastern Pacific and an increase in the catch of these fish in the western Pacific would be expected if fewer age- 0 and age-1 fish migrated. While tagging data are not available prior to 1979, tagging data for 1979-1988 suggest that interannual variation in the proportion of bluefin migrating to the eastern Pacific occurs (Bayliff et al., 1991), and so it is
Figure 5. Catch-at-age of northern bluefin (thousand fish) in the western Pacific Ocean during 1965-1975 and 19801990.

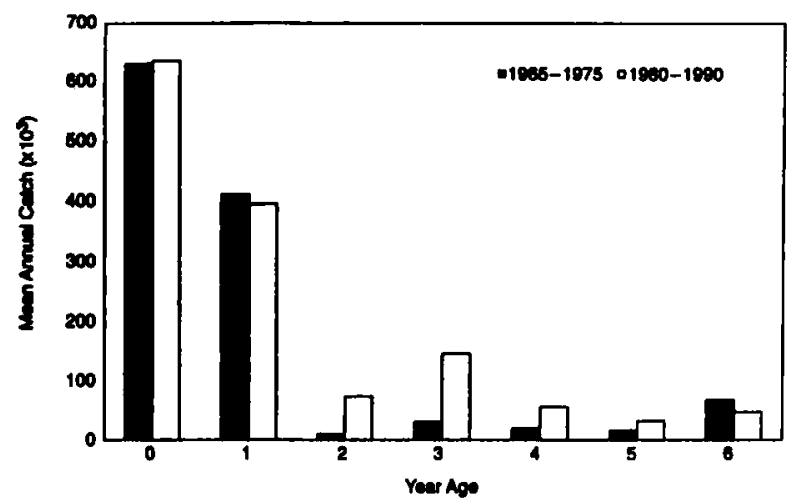

reasonable that variation in the migration proportion could also occur on decadal scales.

It has long been recognized that the Japanese sardine is an important prey of bluefin in the western Pacific (Kida, 1936; Yamanaka et al., 1963; Bayliff, 1994). As far back as 1936, Japanese fishermen reported observing bluefin following schools of migrating sardines (Kida, 1936). Dramatic decadal-scale temporal and spatial variation of the Japanese sardine has been documented (Kawasaki, 1991). For example, from the mid 1970s to the mid 1980s, catches of Japanese sardines from all areas around Japan increased ninefold, from 0.5 to 4.5 tonnes (Kawasaki, 1991). During the 1980s, Japanese

Figure 6. Proportion of age 1-4 northern Pacific bluefin caught in the western Pacific relative to combined eastern and western Pacific catches overlaid with north Pacific landings of sardine.

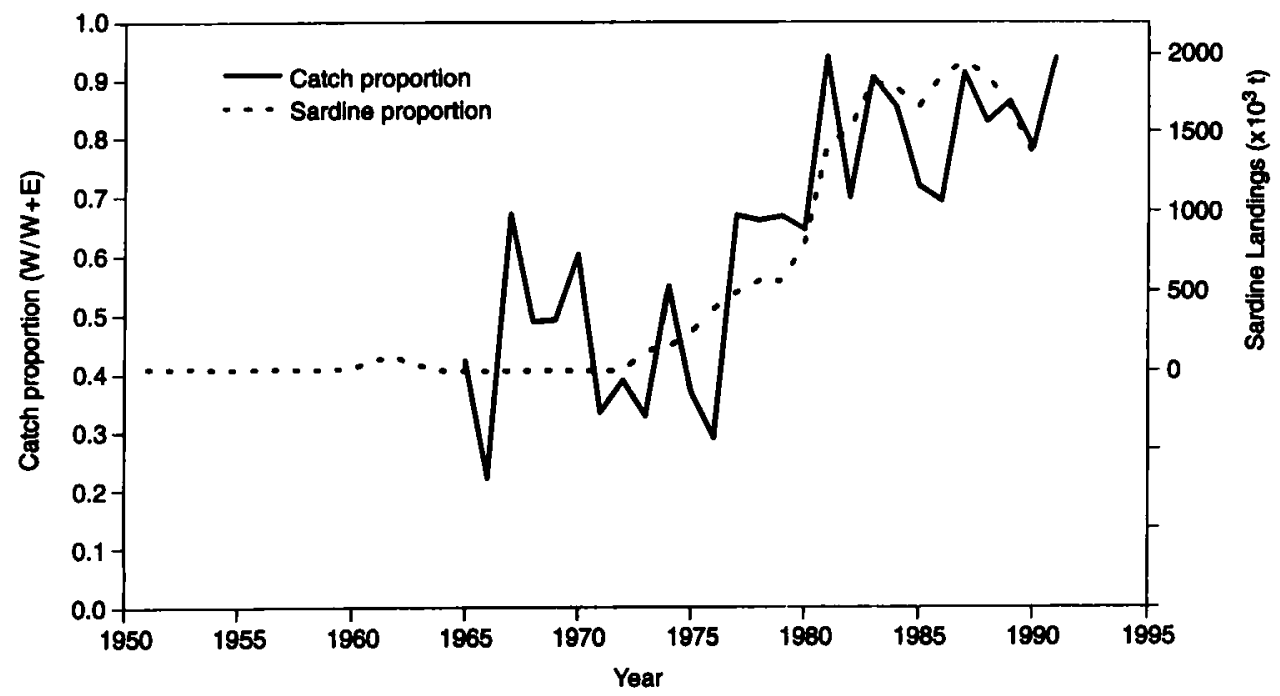


Figure 7. CPUE (number of age $1-4$ bluefin day $^{-1}$ of fishing) in the eastern Pacific overlaid with north Pacific sardine landings.

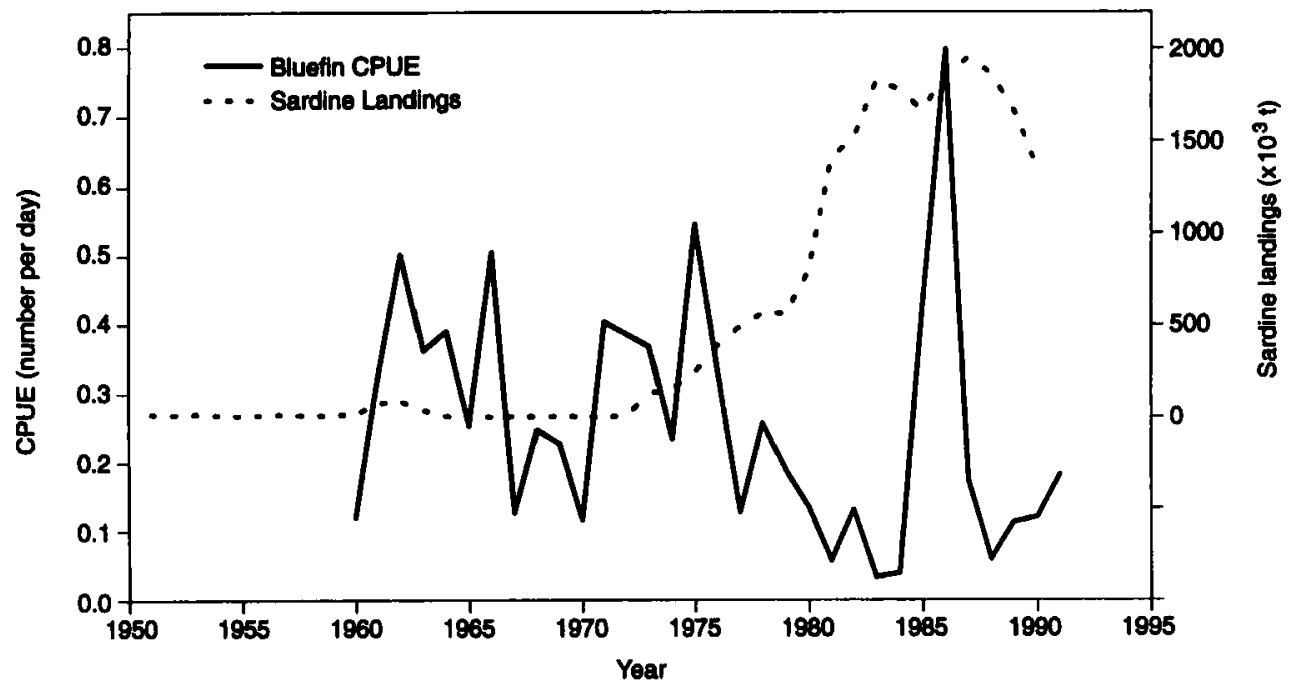

sardine accounted for approximately $25 \%$ of all fishery landings in the north-western Pacific (Stamatopoulos, 1993). The spatial variation is equally dramatic. During periods of low population size, sardines migrate to nearshore winter spawning grounds well inshore of the Kuroshio Current. However, when sardines were abundant winter spawning grounds were located farther offshore in the Kuroshio Current (Kuroda, 1988). Likewise, summer feeding grounds have an eastward limit of about $160^{\circ} \mathrm{E}$ during periods of low abundance, but extend eastward to the international date-line during periods of high abundance (Wada and Kashiwai, 1991). While the mechanism responsible for this population variation is not known, it is thought to be due to climate variation. Decadal variation in sardine abundance off California due to climate forcing is suggested from long time series of scales collected from varved cores (Soutar and Isaacs, 1974).

While the actual mechanism triggering a decision by juvenile bluefin to migrate eastward is unknown, abundance and location of prey are probably important. During periods of low sardine abundance, sardines migrate to coastal habitats inshore of the Kuroshio for winter spawning (Kuroda, 1988). During this time, juvenile bluefin may seek other offshore prey in the Kuroshio and Kuroshio Extension such as squids, leading to an eastward foraging migration. However, when sardines are abundant, the winter spawning occurs offshore in the Kuroshio, and this available prey for bluefin during winter may reduce the need for an eastward foraging migration.
The catch of sardines in the North Pacific shows strong coherence with the decadal trend in the relative catch of age- 1 to age- 4 bluefin in the western Pacific, and the catch and CPUE in the eastern Pacific. However, during the 1980s there is some strong interannual variation in tagging data which suggest that a higher proportion of 1983- and 1984-year-class bluefin made the eastward migration than other year classes during the decade (IATTC, 1994). These year classes appeared as 2-year-olds in the 1985 and 1986 eastern Pacific catch and accounted for the high CPUEs. The sardine catches in 1983 or 1984 do not explain the apparent increase in eastward migration. However, it is possible that the spatial distribution of sardines in these years was different from that in other years in the 1980s, such that it resulted in a higher migration proportion even though sardine biomass was unchanged. It is also likely that a variety of factors contribute to interannual variation in migration, tag returns, and CPUE and it is unrealistic that sardine abundance and distribution will account for all the variation in these variables.

Relatively localized shifts in distribution and migration routes have been observed for a variety of pelagic species, including anchovies, sardines, Pacific whiting, Fraser River sockeye salmon, and humpback whales off South Africa (Quinn and Brodeur, 1991; Best et al., 1995). For example, in the case of the humpbacks off South Africa, it was concluded that their southward migration to Antarctica was suspended for at least 45 days in response to locally abundant prey (Best et al., 1995). 
The apparent decline in the proportion of bluefin that migrate to the eastern Pacific hypothesized in this paper represents the first description of possible decadalscale changes in trans-Pacific migration dynamics linked to regional prey abundance and distribution. Further evidence to test this hypothesis would be an increase in bluefin catches and CPUE in the eastern Pacific if the Japanese sardine population continues to decline.

\section{ACKNOWLEDGEMENT}

I gratefully acknowledge the contribution of Yoshio Ishizuka, National Research Institute of Far Seas Fisheries, Shimizu, Japan for providing recent western Pacific bluefin catch-at-age data.

\section{REFERENCES}

Bayliff, W.H. (1993) Growth and age composition of northern bluefin tuna, Thunnus thynnus, caught in the eastern Pacific Ocean, as estimated from length-frequency data with comments on trans-Pacific migrations. IATTC Bull. 20:503-540.

Bayliff, W.H. (1994) A review of the biology and fisheries for northern bluefin tuna, (Thunnus thynnus), in the Pacific Ocean. In: Interactions of Pacific Tuna Fisheries. R.S. Shomura, J. Majkowski, and S. Langim (eds). FAO Fish. tech. Paper 336/2, 244-295.

Bayliff, W.H. (1996) Indices of abundance of northern bluefin tuna, Thunnus thynnus, in the eastern Pacific Ocean: a key element in assessment of the interaction of the fisheries for this species in the eastern and western Pacific Oceans. In: Second FAO Expert Consultation on Interactions of Pacific Tuna Fisheries R.S. Shomura, J. Majkowski, and S. Langim (eds). FAO Fish. tech. Paper (in press).

Bayliff, W.H., Ishizuka, Y., and Deriso, R. (1991) Growth, movement, and attrition of northern bluefin tuna, Thunnus thynnus, in the Pacific ocean, as determined by tagging. IATTC Bull. 20:3-94.
Best, P.B., Sekiguchi, K., and Findlay, K.P. (1995) A suspended migration of humpback whales Megaptera novaeangliae on the west coast of South Africa. Mar. Ecol. Prog. Ser. 118:1-12.

Foreman, T.J., and Ishizuka, Y. (1990) Giant bluefin off southern California, with a new California size record. Calif. Fish Game 76:181-186.

IATTC (1994) Annual report of the Inter-American Tropical Tuna Commission 1993. La Jolla, Calif: IATTC, 316 pp.

Kawai, H. (1993) Dynamic distribution of major coastal pelagic fish around Japan on a macroscopic scale - I. Time-space distribution of catch for each species. Bull. Jap. Soc. Fish. Ocean. 57:1-8.

Kawasaki, T. (1991) Long-term variability in the pelagic fish populations. In: Long-term Variability of Pelagic Fish Populations and their Environment. T. Kawasaki, S. Tanaka, Y. Toba, and A. Taniguchi (eds). Pergamon Press, Oxford, pp. 47-60.

Kida, T. (1936) On the surface temperature of water in the tunny fishing grounds off Kusiro and Urakawa in summer. Bull. Jap. Soc. Scient. Fish. 5:87-90.

Kuroda, K. (1988) Yearly changes of main spawning grounds of the sardine, Sardinops melanostictus, in the waters along the Pacific coast of southern Japan. Bull. Jap. Soc. Fish. Ocean. 52:289-296.

Quinn, T., and Brodeur, R. (1991) Intra-specific variations in the movement patterns of marine animals. Am. Zool. 31:231-241.

Soutar, A., and Isaacs, J.D. (1974) Abundance of pelagic fish during the 19th and 20th centuries as recorded in anaerobic sediments off Californias. Fish. Bull. 72:257-273.

Stamatopoulos, C. (1993) Trends in catches and landings, Pacific fisheries: 1970-1991. Rome: FAO, FAO Fish. Circ. No. 855.3, $213 \mathrm{pp}$.

Sund, P.N., Blackburn, M., and Williams, F. (1981) Tunas and their environment in the Pacific Ocean. In: Oceanography and Marine Biology, Vol. 19. M. Barnes (ed.). Aberdeen: Aberdeen University Press, pp. 443-512.

Wada, T., and Kashiwai, M. (1991) Changes in growth and feeding ground of Japanese sardine with fluctuation in stock abundance. In: Long-term Variability of Pelagic Fish Populations and their Environment. T. Kawasaki, S. Tanaka, Y. Toba, and A. Taniguchi (eds). Pergamon Press, Oxford, pp. 181-190.

Yamanaka, H., and staff (1963) Synopsis of biological data on kuromaguro Thunnus orientalis (Temminck and Schlegel) 1942 (Pacific Ocean). FAO Fish. Rep. 6:180-217. 